\title{
Erratum: Dynamic SUMO modification regulates mitotic chromosome assembly and cell cycle progression in Caenorhabditis elegans
}

Federico Pelisch, Remi Sonneville, Ehsan Pourkarimi, Ana Agostinho, J Julian Blow, Anton Gartner \& Ronald T. Hay

Nature Communications 5:5485 doi: 10.1038/ncomms6485 (2015); Published 5 Dec 2014; Updated 12 Feb 2015

This Article contains errors in the legends to Supplementary Movies 9-11, which attribute fluorescence to cells expressing mCherry-H2B/GFP-AIR-2. These cells express mCherry-SMO-1(GG)/GFP-H2B. There is also an error in Fig. 1e that was introduced during the production process and resulted in the error bars for the $100 \mathrm{~s}$ time point being displaced to an incorrect position. The correct version of this figure appears below. 
a

PN migration

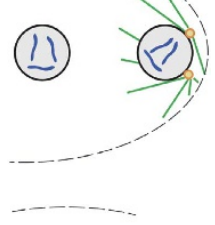

NEBD

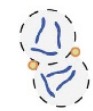

Metaphase
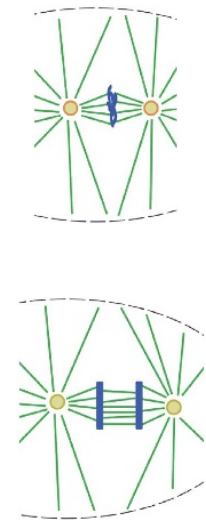

: Centrosome /: Microtubule

: Nuclear envelope : DNA b

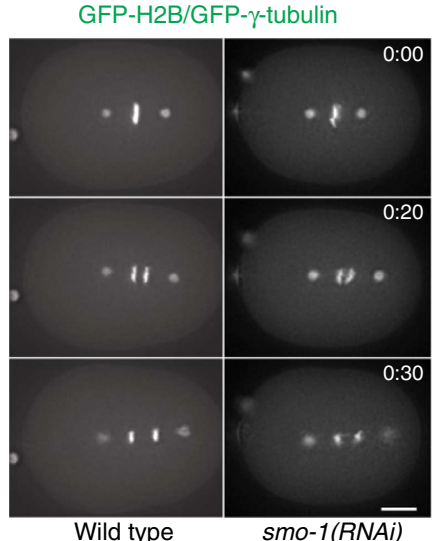

d

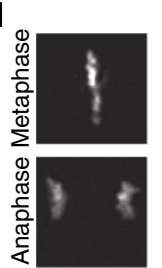

mCherry-H2B
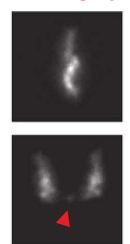

Wild type smo-1(RNAi) ubc-9(RNAi) ulp-4(RNAi)

e

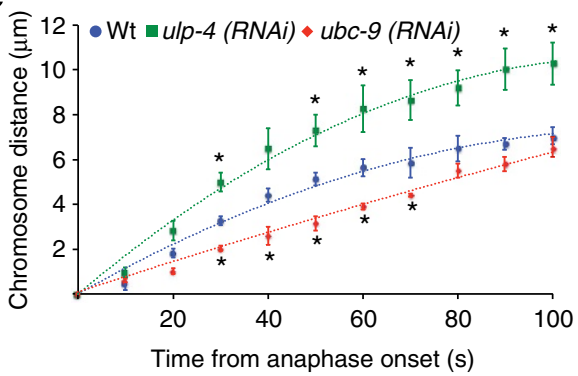

c

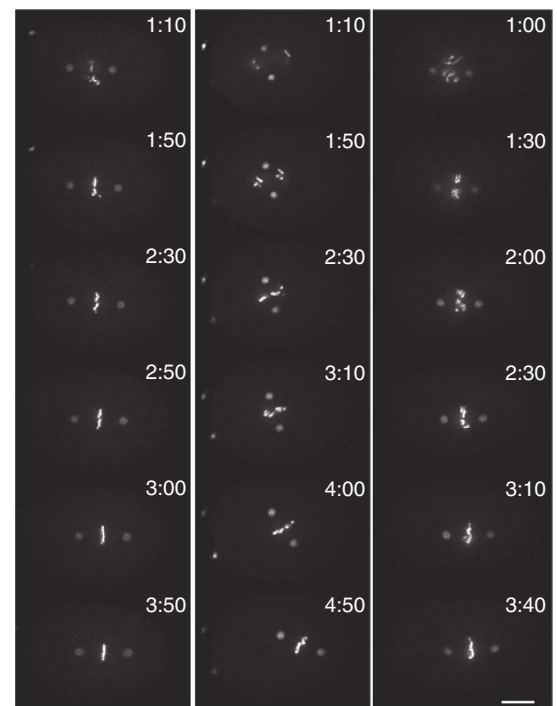

Wild type

ulp-4(RNAi)

$u b c-9(R N A i)$

f

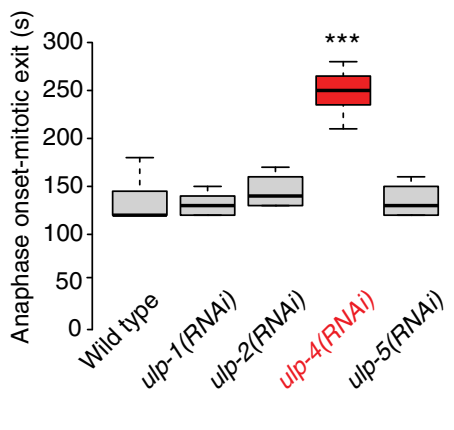

Figure 1 